\title{
Equity Level of Health Insurance Ownership in Indonesia
}

\section{Tingkat Ekuitas Kepemilikan Jaminan Asuransi Kesehatan di Indonesia}

\author{
Risky Kusuma Hartono
}

\author{
Sekolah Tinggi Ilmu Kesehatan Indonesia Maju, Jakarta, Indonesia
}

\begin{abstract}
Social health insurance from government program are expected to be able to reduce inequalities access to health services in the middle of rising of health care cost, while private health insurance is still limited for up and middle class population. This study aimed to analyze the equity level of health insurance ownership including social and private health insurance in Indonesia. This study examined the condition of Indonesia in the middle of entering National Health Insurance (NHI) era. This study used data of Indonesian Socio-Economic Survey 2012. Data were analyzed by using econometric approach through multinomial logit analysis. The results showed that the concentration index of social health insurance ownership was 0.615 , which is smaller than private health insurance ownership (0.972). It means that Indonesia social health insurace ownership will be able to increase equity access to the health services especially for poor people (pro poor). Social health insurance ownership increases the use of the health services by people.
\end{abstract}

Keywords: Concentration index, equity, health insurance, multinomial logit

\begin{abstract}
Abstrak
Jaminan kesehatan sosial dari program pemerintah diharapkan dapat mengurangi ketidakmerataan akses pelayanan kesehatan di tengah meningkatnya biaya kesehatan, sementara jaminan kesehatan swasta masih terbatas untuk populasi kelas menengah dan atas. Penelitian ini bertujuan untuk menganalisis tingkat ekuitas kepemilikan jaminan asuransi kesehatan sosial maupun swasta di Indonesia. Penelitian ini mengkaji hasil lanjutan penelitian tersebut di tengah memasuki era Jaminan Kesehatan Nasional. Data penelitian menggunakan data Survei Sosial Ekonomi Nasional tahun 2012 dengan pendekatan secara ekonometri melalui analisis multinomial logit. Hasil menunjukkan indeks konsentrasi kepemilikan jaminan asuransi kesehatan sosial sebesar 0,615 memiliki nilai lebih kecil dari kepemilikan jaminan asuransi kesehatan swasta sebesar 0,972. Secara empiris, temuan ini membuktikan bahwa kepemilikan jaminan asuransi kesehatan sosial membuka pintu gerbang lebar terhadap akses ekuitas ke pelayanan kesehatan yang bersifat pro poor. Impelementasinya, kepemilikan jaminan asuransi kesehatan sosial meningkatkan penggunaan pelayanan kesehatan oleh masyarakat.
\end{abstract}

Kata kunci: Indeks konsentrasi, ekuitas, asuransi kesehatan, multinomial logit

How to Cite: Hartono RK. Equity level health insurance ownership in Indonesia. Kesmas: National Public Health Journal. 2017; 12 (2): 93-100. (doi:10.21109/kesmas.v12i2.1408)
Correspondence: Risky Kusuma Hartono, Sekolah Tinggi Ilmu Kesehatan Indonesia Maju, Harapan Street No.50 Lenteng Agung, South Jakarta 12610 Indonesia, Phone: +6221-78894043, e-mail: risky_kusuma@yahoo.com

Received: January $19^{\text {th }} 2017$

Revised: September 6 $6^{\text {th }} 2017$

Accepted: September $27^{\text {th }} 2017$ 


\section{Introduction}

Health care costs continue to increase. Examples of cases occur in the United States of America, the cost spent for Per Capita Expenditure (PCE) for health care goods and services in 1999-2012 is higher than the PCE for all goods and services. ${ }^{1}$ Inflation from health sector also happens on other continents, such as in Asia increased by $4.2 \%$ per year, Africa $6.6 \%$ per year, and Europe with the situation fairly controlled at $1.6 \%$ per year. ${ }^{2}$ Based on this rising inflation, rich and poor people require to protect financial risks due to illness conditions, one of which is through the principle of risk transfer from health insurance for all. ${ }^{3}$ This protection is needed especially in developing countries in order to avoid "Sadikin" (poor after sick). ${ }^{4}$

Efforts in prevention of "Sadikin" after getting sick and utilization of hospital now increasingly get international attention. The World Health Organization (WHO) since 2000 has encouraged countries the establishment of Universal Health Coverage (UHC). UHC is actualized through extended to non-coverage users, reduced fees and sharing, including other services. ${ }^{5} \mathrm{UHC}$ is as the embodiment of social health insurance. ${ }^{6} \mathrm{UHC}$ is expected to focus not only on curative care, but also have adequate focus on health promotion and disease prevention. ${ }^{7}$

The Indonesian government makes a real embodiment of UHC through the implementation of Law No. 40 of 2004 on National Social Security System (Sistem Jaminan Sosial Nasional/SJSN). This Social Security Law mandated the Indonesian people to have social protection through Jaminan Kesehatan Nasional or National Health Insurance (NHI). ${ }^{8}$ The policy mandates to the Social Security Agency (BPJS Kesehatan) as a program organizer of Indonesia NHI. In sum, the nation's public health insurance programs such as NHI have many important in short and long term poverty reducing benefits for low-income families with children. ${ }^{9}$

$B P J S$ Kesehatan is a merging body from PT Askes, JPK Jamsostek, Jamkesmas, and Jamkesda. PT Askes initially only provided health coverage for governing body and civil servants. With reference to Act No. 24 of 2011 on BPJS, PT Askes, JPK Jamsostek, Jamkesmas, and Jamkesda, then it transformed into BPJS Kesehatan. ${ }^{10}$ These agencies transform to manage health insurance for entire population of Indonesia.

Various factors influence demand for health insurance. Kirigia et al, ${ }^{11}$ explained that demographic factors such as age, sex, income, occupation, area of residence, and the risk of certain illness influence the demand for health insurance. In addition, Jin and Hou, ${ }^{21}$ have concluded that individual characteristics tend to have a social health insurance, private health insurance, or have social and private health insurance in terms of a series of demographic characteristics. ${ }^{12}$ These results showed that the people in urban areas tend to choose to have a private health assurance. This will result in health insurance as a luxurious or inferior product.

In Indonesia, based on results of study by Hidayat, ${ }^{13}$ the ownership of social health insurance (Askes and Jamsostek) opens the gate to reduce inequalities in access to health services compared to private health insurance ownership. Moreover, the near-poor population in Indonesia is until $37.42 \%$ and $0.01 \%$ of the population is below the poverty line. ${ }^{14}$ Supposedly, vision of UHC conducted through National Health Insurance (NHI) program in Indonesia through social health insurance ownership will be able to reduce disparities.

Health insurance is required as a financial safeguard in the event of illness, especially from burden of cost. Private insurance companies have been seen as a business development opportunities to target buyers from the middle income up to the top level. ${ }^{15}$ Based on data from the Indonesia National Socio-Economic Survey 2012, approximately, as much as $9 \%$ of Indonesia's population have private health insurance. Also, based on the report of the Indonesian Life Insurance Association (AAJI), there are more than 40 life insurance companies with more than 450 marketer agents that are ready for market life and private health insurance products in Indonesia. ${ }^{16}$ Meanwhile, these conditions potentially create market failures and do not necessarily guarantee the creation of equity conditions.

The concept of equity in health care is the equality for the population to get access to health services regardless their socio-economic status through health insurance ownership. ${ }^{17}$ The presence of Indonesia NHI program allegedly expands the access to health care insurance policy on all elements of society (rich and poor). This study tried to analyze and prove this statement. This study was conducted in order to embody the equity access of health services to realize the five principles (Pancasila) of the Republic of Indonesia that stated social justice for all people.

\section{Method}

This cross-sectional study was used secondary data, namely Indonesian National Socio-Economic Survey in 2012, which represents an overview of socio-economic situation of Indonesia in 2012. Indonesian National Socio-Economic Survey is done every year with consisting of two sets of questionnaires that are the Kor questionnaire (VSEN12-M-PNL) and housing and health questionnaire module (VSEN12-K-PNL). The sample used in this study was the individual from household as many as 279,581 people from 33 provinces.

Dependent variable was health insurance ownership that were categorized into more than two groups. These categories had no insurance, had social health insurance, 
private health insurance, and double insurance from social and private insurance. Social health insurance ownership as an Indonesia NHI variable is formed from membership of PT Askes, JPK Jamsostek, JAMKESMAS, and Jamkesda. ${ }^{18}$

The independent variables of this study were taken from the theories discussed before. These variables include sociodemographic conditions, education level, employment, illness condition, and outpatients' visit to the health services. Besides, measurements of economic status is as a proxy variable from income as a home ownership status, house floor, electrical installation, computer ownership, poverty, per capita expenditure, and food expenditure. Measurement was held to analyze the nature of ownership of health insurance coverage that is either more pro-rich or pro-poor.

Univariate analysis displays the number of observations $(\mathrm{N})$, the average of each variable which is in categorical data average values represent the proportion from amount of mean of variables. In addition, there is a standard deviation (SD), minimum and maximum values of each variable. The bivariate analysis was done to determine the differences between groups conducted by displaying the number and average (mean) of each category.

Study used econometric modeling with multinomial logit analysis. Multinomial logit analysis calculation produced coefficient beta and relative risk ratio (RRR) for all independent variables. This study study explored the relation between a set of independent variables that explain the possibility of individuals who choose one of the categories of health insurance compared to the other cate- gories. In this model, NHI was selected as comparator category (base outcome) with the other groups. This study also assessed the assumption of independence of irrelevant alternatives (IIA) test. The analysis results support the IIA and the odds of each category of health insurance ownership.

The level of fairness (equity) were presented in graphical form, known as the concentration curves and consentration index. ${ }^{17,19}$ Concentration curve presented the cumulative distribution of health insurance ownership that located on the Y axis, and the cumulative distribution of the number of people that were sorted based on average household consumption expenditure per capita on the $\mathrm{X}$ axis. A 45-degree line that divided diagonally between the two axes ( $\mathrm{X}$ and $\mathrm{Y}$ ) is the line of equity. This line indicates the level of fairness in access of entire group of people to the health services.

Range value the measurement of concentration index is from -1 to $+1 .{ }^{19}$ Score of concentration index which is positive index indicates a gap in access to the health services that lead to richer groups (pro-rich). Otherwise, negative index indicates that the easier access to the health services lead to poorer groups (pro-poor).

\section{Results}

Table 1 illustrates the demographic characteristics of ownership of health insurance demand. In the Table 1, the number of sample is 279,581 . There are categorical and numerical variables. The average Per Capita Consumption (PCE) is 600,000.

Based on Table 1, the characteristics associated with equity like the proportion of people who ever be outpa-

Table 1. Demographic Characteristic of Insurance Ownership Demand

\begin{tabular}{|c|c|c|c|c|}
\hline Variable & Mean & SD & Min & Max \\
\hline Urban & 0.428 & 0.494 & 0 & 1 \\
\hline HH member & 2.858 & 1.725 & 1 & 22 \\
\hline Female & 0.498 & 0.500 & 0 & 1 \\
\hline Age & 29.06 & 19.92 & 0 & 98 \\
\hline Married & 0.470 & 0.499 & 0 & 1 \\
\hline Years education & 5.430 & 4.313 & 0 & 22 \\
\hline Work status & 0.452 & 0.498 & 0 & 1 \\
\hline Own house & 0.829 & 0.376 & 0 & 1 \\
\hline Floor tile & 0.276 & 0.447 & 0 & 1 \\
\hline Using lighting & 0.904 & 0.295 & 0 & 1 \\
\hline PC Desktop ownership & 0.0622 & 0.242 & 0 & 1 \\
\hline Outpatient & 0.133 & 0.339 & 0 & 1 \\
\hline Morbidity & 0.198 & 0.398 & 0 & 1 \\
\hline Car ownership & 0.0826 & 0.275 & 0 & 1 \\
\hline Poor & 0.131 & 0.338 & 0 & 1 \\
\hline Per capita consumption & 623,370 & 187,863 & 67,075 & $75,300,000$ \\
\hline Food consumption & $1,437,000$ & 912,269 & 77,143 & $22,130,000$ \\
\hline Healthcare distance & 25.25 & 19.23 & 1.594 & 102.8 \\
\hline Health insurance type & 0.448 & 0.570 & 0 & 3 \\
\hline
\end{tabular}


tients was $13.3 \%$. People with sick condition were $19.8 \%$ and poor economic status $(13.1 \%)$. Based on asset ownership, $82.9 \%$ people had own home, but only $8.2 \%$ had own car. The characteristics of health insurance ownership are presented in the Figure 1.

Figure 1 describes health insurance ownership in percentage in 2012. There were $58.7 \%$ people still unregistered as a membership of NHI. NHI in that year was still not implemented yet. Therefore, this enrollment is created through the proxy and estimation from enrollment of PT Askes Persero, Jamsostek, Jamkesmas, and Jamkesda. There were $38.23 \%$ proportion of NHI member. This figure also describes the enrollment proportion of private insurance that was $2.68 \%$.

Table 2 illustrates the determinants of health insur-

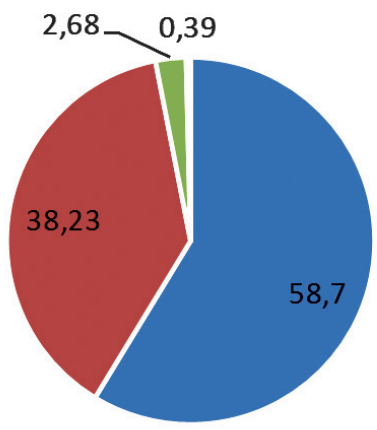

$$
\begin{aligned}
& \text { - 1. Don't have insurance (58.7\%) - 2. Indonesia NHI (38.23\%) } \\
& \text { " 3. Private Insurance (2.68\%) - 4. Double Insurance (0.39\%) }
\end{aligned}
$$

Figure 1. Health Insurance Ownership Percentage ance ownership by type of health insurance. This table describes the amount or proportion of socio-demographic conditions compared to the health insurance ownership. The maximum observation number is still for uninsured people.

Based on Table 2, outpatients' visits were mostly accessed by double insurance ownership as much as $14 \%$ of these participants. However, private and double insurance ownership were characteristically from rich economic status, which was seen from house ownership, tile floors and desktop PC ownership that had higher proportion than uninsured and NHI insurance. While uninsured people had a smaller proportion of outpatients' visits to the health services than people member of NHI. This indicates that people who had private health insurance had easy access to the health services. Moreover, people who did not have health insurance had more difficult access to the health services than people who had NHI. Then, Table 3 shows the multivariate analysis.

Table 3 shows that the determinant of health insurance ownership was influenced by significant factors and RRR value. In this case, the uninsured was a baseline outcome. People with poor status tend to be NHI participants 1.31 times compared to be uninsured. Besides, the increasing person of household member tend to be a NHI participant 1.04 times compared to become uninsured. People who had asset of desktop PC tend to be have private health insurance 2.14 times compared to become uninsured. People with ill condition tend to have double health insurance 1.29 times compared to become uninsured.

\begin{tabular}{|c|c|c|c|c|c|c|c|c|}
\hline \multirow[t]{2}{*}{ Variables } & \multicolumn{2}{|c|}{$\begin{array}{l}\text { Uninsured } \\
(\mathrm{N}=164,121)\end{array}$} & \multicolumn{2}{|c|}{$\begin{array}{c}\text { Indonesia NHI } \\
(\mathrm{N}=106,871)\end{array}$} & \multicolumn{2}{|c|}{$\begin{array}{l}\text { Private Insurance } \\
\qquad(\mathrm{N}=7,489)\end{array}$} & \multicolumn{2}{|c|}{$\begin{array}{l}\text { Double Insurance } \\
\qquad(\mathrm{N}=1,100)\end{array}$} \\
\hline & Mean & Max & Mean & Max & Mean & Max & Mean & Max \\
\hline Urban & 0.582 & 1 & 0.592 & 1 & 0.210 & 1 & 0.329 & 1 \\
\hline HH member & 2.857 & 22 & 2.855 & 18 & 3.001 & 14 & 2.249 & 9 \\
\hline Female sex & 0.493 & 1 & 0.503 & 1 & 0.475 & 1 & 1 & 1 \\
\hline Age & 28.93 & 98 & 29.33 & 98 & 27.10 & 98 & 36.70 & 81 \\
\hline Marital status & 0.477 & 1 & 0.457 & 1 & 0.442 & 1 & 0.994 & 1 \\
\hline Years of education & 5.283 & 22 & 5.486 & 22 & 7.195 & 22 & 9.776 & 22 \\
\hline Work Status & 0.471 & 1 & 0.421 & 1 & 0.445 & 1 & 0.586 & 1 \\
\hline Own house & 0.826 & 1 & 0.842 & 1 & 0.744 & 1 & 0.754 & 1 \\
\hline Floor tile & 0.276 & 1 & 0.248 & 1 & 0.626 & 1 & 0.547 & 1 \\
\hline Using lighting & 0.910 & 1 & 0.888 & 1 & 0.985 & 1 & 0.977 & 1 \\
\hline PC desktop ownership & 0.0478 & 1 & 0.0678 & 1 & 0.274 & 1 & 0.225 & 1 \\
\hline Outpatient & 0.117 & 1 & 0.157 & 1 & 0.144 & 1 & 0.140 & 1 \\
\hline Illness experience & 0.186 & 1 & 0.214 & 1 & 0.222 & 1 & 0.185 & 1 \\
\hline Car ownership & 0.0731 & 1 & 0.0777 & 1 & 0.338 & 1 & 0.232 & 1 \\
\hline Poor status & 0.124 & 1 & 0.151 & 1 & 0.0294 & 1 & 0.0400 & 1 \\
\hline Per capita consumption & 594,850 & $7.530 \mathrm{e}+07$ & 612,143 & $7.530 \mathrm{e}+07$ & $1.335 \mathrm{e}+06$ & $4.741 \mathrm{e}+07$ & $1.124 \mathrm{e}+06$ & $7.530 \mathrm{e}+07$ \\
\hline Food consumption & $1.401 \mathrm{e}+06$ & $2.213 e+07$ & $1.426 \mathrm{e}+06$ & $1.275 \mathrm{e}+07$ & $2.283 e+06$ & $1.131 \mathrm{e}+07$ & $2.169 \mathrm{e}+06$ & $1.131 \mathrm{e}+07$ \\
\hline Healthcare distance & 25.11 & 102.8 & 25.72 & 102.8 & 22.22 & 93.48 & 21.85 & 98.88 \\
\hline
\end{tabular}

Table 2. Socio-demographic Conditions Based on Ownership of Health Insurance

Note:

$\mathrm{N}=$ Number of Sample 
Table 3. Multivariate Analysis of Health Insurance Ownership Determinant

\begin{tabular}{|c|c|c|c|c|c|c|c|}
\hline \multirow{3}{*}{ Variable } & \multirow{3}{*}{ Category } & \multicolumn{6}{|c|}{ Health Insurance Ownership $(\mathrm{n}=279,581$ and Pseudo $R-2=0.0426)$} \\
\hline & & \multicolumn{2}{|c|}{ NHI } & \multicolumn{2}{|c|}{ Private Insurance } & \multicolumn{2}{|c|}{ Double Insurance } \\
\hline & & p Value & $\operatorname{RRR}(95 \%$ CI) & p Value & RRR $(95 \%$ CI) & p Value & $\mathbf{R R R}(95 \% \mathbf{C I})$ \\
\hline \multirow[t]{2}{*}{ Urban } & Urban & $<0.01$ & $0.96(0.95-0.96)$ & & $0.98(0.97-0.99)$ & $<0.01$ & $0.79(0.76-0.82)$ \\
\hline & Rural & & 1 & & 1 & & 1 \\
\hline \multirow[t]{2}{*}{ Sex } & Female & & $0.99(0.98-1.01)$ & $<0.01$ & $0.92(0.90-0.95)$ & & $5.98(-3.96-3.97)$ \\
\hline & Male & & 1 & & 1 & & 1 \\
\hline \multirow[t]{2}{*}{ House ownership } & Own house & $<0.01$ & $1.12(1.11-1.13)$ & $<0.01$ & $0.61(0.59-0.63)$ & $<0.01$ & $0.78(0.72-0.84)$ \\
\hline & Otherwise & & 1 & & 1 & & 1 \\
\hline \multirow[t]{2}{*}{ Car ownership } & Own car & & $0.97(0.95-0.99)$ & $<0.01$ & $1.95(1.89-2.01)$ & & $1.03(0.94-1.12)$ \\
\hline & Otherwise & & 1 & & 1 & & 1 \\
\hline \multirow[t]{2}{*}{ Floor tile } & Floor tile & $<0.01$ & $0.80(0.79-0.80)$ & $<0.01$ & $1.88(1.82-1.93)$ & $<0.01$ & $1.52(1.41-1.63)$ \\
\hline & Otherwise & & 1 & & 1 & & 1 \\
\hline \multirow[t]{2}{*}{ Have PC desktop } & Own PC desktop & $<0.01$ & $1.47(1.44-1.50)$ & $<0.01$ & $2.14(2.07-2.21)$ & $<0.01$ & $2.09(1.90-2.27)$ \\
\hline & Otherwise & & 1 & & 1 & & 1 \\
\hline \multirow{2}{*}{ Marital status } & Married & $<0.01$ & $0.88(0.87-0.89)$ & $<0.1$ & $0.94(0.90-0.97)$ & $<0.01$ & $164.5(100.7-228.2)$ \\
\hline & Single & & 1 & & 1 & & 1 \\
\hline \multirow[t]{2}{*}{ Employment status } & Work & $<0.01$ & $0.71(0.39-0.71)$ & $<0.05$ & $0.92(0.89-0.95)$ & & $0.97(0.90-1.03)$ \\
\hline & Otherwise & & 1 & & 1 & & 1 \\
\hline \multirow[t]{2}{*}{ Using lighting } & Lighting & $<0.01$ & $0.79(0.78-0.81)$ & $<0.01$ & $1.65(1.48-1.81)$ & & $1.40(1.10-1.71)$ \\
\hline & Otherwise & & 1 & & 1 & & 1 \\
\hline \multirow[t]{2}{*}{ Outpatient } & Outpatient & & $1.36(1.34-1.38)$ & $<0.01$ & $1.19(1.24-1.15)$ & & $1.13(1.24-1.03)$ \\
\hline & Otherwise & & 1 & & 1 & & 1 \\
\hline \multirow[t]{2}{*}{ Illness experience } & Morbid & $<0.01$ & $1.07(1.06-1.09)$ & $<0.01$ & $1.16(1.14-1.20)$ & $<0.01$ & $1.29(1.18-1.40)$ \\
\hline & Otherwise & & 1 & & 1 & & 1 \\
\hline \multirow{2}{*}{ Poor status } & Poor & $<0.01$ & $1.31(1.29-1.33)$ & $<0.01$ & $0.61(0.56-0.65)$ & & $0.93(0.78-1.08)$ \\
\hline & Otherwise & & 1 & & & & 1 \\
\hline Age & Years & $<0.01$ & $1.04(1.03-1.04)$ & $<0.01$ & $0.94(0.93-0.95)$ & $<0.01$ & $0.95(0.91-0.98)$ \\
\hline HH member & Person & $<0.01$ & $1.04(1.03-1.05)$ & $<0.01$ & $0.42(0.41-0.44)$ & $<0.01$ & $0.73(0.67-0.78)$ \\
\hline Per capita consumption & n Rupiah & $<0.05$ & 1 & $<0.01$ & 1 & $<0.05$ & 1 \\
\hline Healthcare distance & $\mathrm{km}$ & & 1 & & $1.001(1.000-1.001)$ & $<0.05$ & $0.96(0.94-0.97)$ \\
\hline Food consumption & Rupiah & $<0.01$ & 1 & $<0.01$ & 1 & $<0.01$ & 1 \\
\hline Years of education & Years & $<0.01$ & $1.02(1.02-1.03)$ & $<0.01$ & $1.02(1.02-1.03)$ & $<0.01$ & $1.09(1.08-1.09)$ \\
\hline Constant & & $<0.01$ & & $<0.01$ & $0.05(0.04-0.06)$ & & \\
\hline
\end{tabular}

Notes:

$\mathrm{RRR}=$ Relative Risk Ratio; NHI= National Health Insurance

Goodnes of Fit (GOF) test showed fistat prob > LR 0.00 . It means that this test was fit. More result of the equity level calculation is done by using consentration curve that can be seen in Figure 2.

Based on Figure 2, NHI health insurance ownership which also includes insurance for poor (Jamkesmas and Jamkesda) had a closer distance to the equity line compared to the ownership of double and private insurance. The result calculation of concentration index of Indonesia NHI ownership was 0.615 which had closer value of 0 (equity line) than private health insurance ownership that was 0.972 . The concentration index of double health insurance ownership was 0.968 . It means that NHI ownership had a higher level of the equity compared to the pivate insurance ownership.

\section{Discussion}

People's choice to participate in the health insurance membership depends on the risk management of each individual. Characteristics risk averse under ideal condi- tions, preferring to pay a premium in a certain amount to shift the risk of illnes. ${ }^{20}$ Unfortunately, these ideal conditions never occur in the real world. Various determinants of health insurance ownership are as a demand. These determinants have vary in various countries depending on socio-demographic conditions of a country. Africa's racial factors also determine the ownership of health insurance. ${ }^{11}$ In China, alcohol drinkers prefer to own the member of health insurance. ${ }^{12}$ While in the USA, cancer patients from disadvantaged communities get most benefits from health insurance, and there is a reduction in disparities in outcome. ${ }^{21}$

The results of this study is an agregate representative of Indonesia, as a determinant of ownership health insurance that is dwelling in urban areas, the number of family members, female sex, age, house ownership, marital status, education level, employment status, ever outpatient visits to health services, having morbid experience, and increasing per capita spending. The results are in line with studies of the determinants of PT Askes par- 

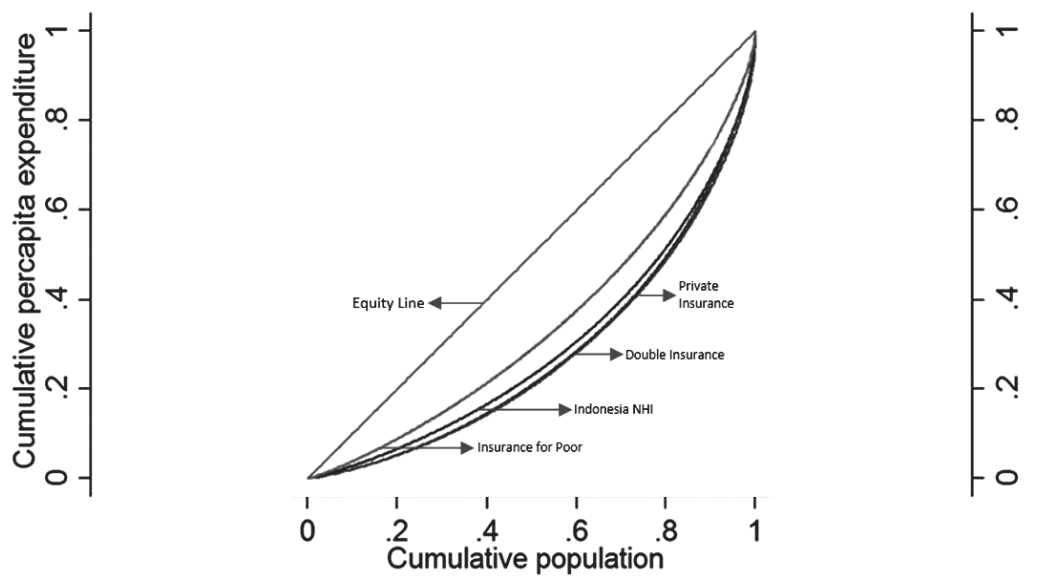

Figure 2. Consentration Curve Based on Health Insurance Ownership

ticipation for civil servants that have the same result with this study. 22

In particular, the ownership of private health insurance covers the higher expenses for meals, has assets of car, house floor tiled, having a computer, higher education level, using lighting in the house, ever made outpatients visits to health care, having illness experience, increased spending per capita. This proves that the ownership of private health insurance in Indonesia is concluding as an inverior goods. In Ireland, the government subsidizes the purchase of private health insurance through measures including tax relief on premiums and not charging the full economic cost for private beds in public hospitals, so this insurance is to be owned. ${ }^{23}$

On the other side, the determinants of Indonesia NHI ownership types include the number of family members, increasing age, higher educational level, ever outpatients' visits to health services, illness experience, poor status, nearer distance to health facilities. Based on these determinants, ownership of Indonesia NHI reduce disparities of health insurance as a superior goods. Among of them, there is an increasing population with a poor status for $\mathrm{NHI}$ registered as participants. It supports the WHO's vision for creating UHC where all the registered population coverage of the health insurance regardless their economic status. ${ }^{5}$ A global landscape of UHC evolution implies that orchestrated international efforts should regard these nations as one of the pillars of any responsible policy in aim to protect the world's poor from health-related risks. ${ }^{24}$

Some of the challenges of BPJS Kesehatan are about encouraging all Indonesian people to participate in the program of Indonesia NHI that reaches the coverage for informal worker sector and encouraging top level managers at private companies to be participants of Indonesia NHI. 25 One of the causes comes from the individual level of manager and higher that only buy pri- vate health insurance and a reluctance to pay double dues. The ownership of private health insurance is increasing participant satisfaction compared to ownership of social health insurance. ${ }^{26}$

Based on the results of the study, the determinants of ownership of double insurance covers is a younger age, asset ownership of car, house floor tiled, computer ownership, marital status, the higher the level of education, and never get sick. These pro-rich characteristics can easily access combine both facilities, primary health care and hospital visit, which make wider inequity significantly. 27

Reflecting this result, young individuals with sufficient financial conditions have to be encouraged to be participants of Indonesia NHI than to purchase private health insurance. In the early stages, BPJS Kesehatan should appeal to those characteristics at manager level and higher to be encouraged to be NHI program participants.

Calculations by using the curve and consentration index indicate that the program NHI opens the gate of equity compared to the ownership of private health insurance. Likewise, having double health insurance ownership also opens the access to the equity compared to only having private health insurance. Unfortunately, the mechanism of Coordination of Benefits (COB) between private health insurance package and NHI package is still being debated. Until 2014, there are only 51 private health insurance companies that signed contracts with BPJS Kesehatan to do COB. ${ }^{28}$ In 2016, BPJS Kesehatan makes a technical regulation in the form of $\mathrm{COB}$ Regulation of BPJS No. 4 Year 2016 on technical guidelines of COB. ${ }^{29}$ This adoption is expected to complete the $\mathrm{COB}$ polemic to improve the equity level of health insurance ownership in Indonesia.

\section{Conclusion}

The results of this study prove that NHI program as 
the social health insurance in Indonesia widely opens the gate of the equity access for poor people (pro-poor) to access the health services. Ownership of health insurance that initially as an inferior product will be accessible to the people through implementation of NHI. The study findings provide suggestion to the government to expand coverage of social health insurance ownership in Indonesia. The government should encourage more individuals in the upper level manager to be incorporated in NHI participants.

\section{References}

1. Council of Economic Advisers. Trends in health care cost growth and the role of the affordable care act. United Stated America: Executive Office of the President of the United Stated; 2013. Available from: https://obamawhitehouse.archives.gov/sites/default/files/docs/healthcostreport_final_noembargo_v2.pdf

2. Hewitt A. 2016 global medical trend rates [Internet]. US: Aaon Hewit Survey Report; 2016. Available from: http://www.aon.com/attachments/human-capital-consulting/2016_Med_Report_US_WEB.pdf

3. Collins SR, Schoen C, Davis K, Gauthier AK, Schoenbaum SC. A roadmap to health insurance for all: principle reform prepared for the commonwealth fund commission on a high performance health system october 2007. Journal Commonwealth [Internet]. 2007; (1066). Available from: http://www.commonwealthfund.org/ /media/ files/publications/fund-report/2007/oct/a-roadmap-to-health-insurance-for-all—principles-for-reform/collins_roadmaphltinsforall_1066pdf.pdf

4. Thabrany H. Pain poverty and milenium development goals (MDGs). Jakarta: Kompas; 2009.

5. World Health Organization. Arguing for universal health coverage. Geneva: World Health Organization; 2013. 39 p.

6. Thabrany H. Indonesia national health insurance. Jakarta: Rajawali Pers; 2014.

7. Coe G, Beyer D. The imperative for health promotion in universal. Journal Global Health Science and Practice [Internet]. 2014; 2(1): 10-22. Available from: https://www.ncbi.nlm.nih.gov/pmc/ articles/PMC4168610/

8. Republik Indonesia. Undang-Undang nomor 40 tahun 2004 tentang sistem jaminan sosial nasional. Jakarta: Republik Indonesia; 2004.

9. Wherry LR, Kenney GM, Sommers BD. The role of public health insurance in reducing child poverty. Academic Pediatrics [Internet]. 2016; 16(3): S98-104. Available from: http://dx.doi.org/10.1016/ j.acap.2015. 12.011

10. Republik Indonesia. Undang-undang nomor 24 tahun 2011 tentang badan penyelenggara jaminan sosial (BPJS Kesehatan). Jakarta: Republik Indonesia; 2012.

11. Kirigia JM, Sambo LG, Nganda B, Mwabu GM, Chatora R, Mwase T. Determinants health insurance ownership among south african women. BMC Health Service Research [Internet]. 2005; 10: 1-10. Available from: https://bmchealthservres.biomedcentral.com/articles/10.1186/1472-6963-5-17

12. Jin Y, Hou Z, Zhang D. Determinants health insurance coverage among people aged 45 and over in China?: who buys public , private and mul- tiple insurance. PLoS One [Internet]. 2016; 1-15. Available from: http://journals.plos.org/plosone/article?id=10.1371/journal.pone.0161 774

13. Hidayat B, Thabrany H, Dong H, Sauerborn R. The effects of mandatory health insurance on equity in access to outpatient care in Indonesia. National Center for Biotechnology Information [Internet]. 2004; 19(5): 322-35. Available from: https://www.ncbi.nlm.nih.gov/pubmed/ 15310667

14. Badan Pusat Statistik. Jumlah penduduk miskin Indonesia 2013 [Internet]. Jakarta: Badan Pusat Statistik; 2013. Available from: https://www.bps.go.id/linkTabelStatis/view/id/1494

15. Liu H, Gao S, Rizzo JA. China economic review the expansion of public health insurance and the demand for private health insurance in rural China. China Economic Review [Internet]. 2011; 22 (1): 25-41. Available from: http://dx.doi.org/10.1016/j.chieco.2010.08.006.

16. Indonesia Life Insurance Association. Report of indonesia life insurance industry performance in the first quarter of 2015 [Internet]. 2015 [cited 2015 Nov 5]. Available from: http://www.aaji.or.id/NewsEvent/aajilaporkan-kinerja-industri-asuransi-jiwa-pada-kuartal-pertama-di-tahun2015

17. Wagstaf, Adam, Bilger M, Sajaia Z, Lokshin M. Health equity and financial protection [Internet]. Washington DC: The Wolrd Bank; 2011. Available from: http://www.worldbank.org/en/topic/health/publication/health-equity-and-financial-protection-datasheets

18. Dewan Jaminan Sosial Nasional Republik Indonesia. Peta jalan menuju jaminan kesehatan nasional 2012-2019. Jakarta: Dewan Jaminan Sosial Nasional Republik Indonesia; 2012.

19. O’Donnell O, van Doorslaer E, Wagstaff A, Lindelow M. Analyzing health equity using household survey data: a guide to techniques and their implementation [Internet]. Washington DC: World Bank; 2008. Available from: http://openknowledge.worldbank.org/handle/10986/6896

20. Feldstein P. Health care economics. USA: Cengage Learning; 2012.

21. Abdelsattar ZM, Hendren S, Wong SL. The impact health insurance on cancer care in disadvantaged communities. American Cancer Society [Internet]. 2016; 123:1219-27. doi:10.1002/cncr.30431. Available from: http://www.ncbi.nlm.nih.gov/pubmed/27859019.

22. Thabrany $\mathrm{H}$. Social health insurance in indonesia: current status and the proposed national health insurance. Present Social Health Insurance Work WHO SEARO, New Delhi, March 13-15, 2003 Revised, August 2003. 2003; (August).

23. Turner B. Unwinding the state subsidisation of private health insurance in Ireland. Health Policy Journal [Internet]. 2015; 119, Issue. Available from: https://doi.org/10.1016/j.healthpol.2015.08.008

24. Jakovljevic M. Commentary: Implementing pro-poor universal health coverage. Journal Frontiers in Public Health [Internet]. 2016; 4(August): 186. Doi: 10.3389/fpubh.2016.00186. Available from: http://journal.frontiersin.org/article/10.3389/fpubh.2016.00186/full

25. Bayu. Tantangan kepesertaan BPJS kesehatan. Jakarta: BPJS Kesehatan; 2016.

26. Fronstin BP, Ph D, Benefit E. Private health insurance exchanges and defined contribution health plans: is it déjà vu all over again? National Center for Biotechnology Information [Internet]. 2012; (373). Available from: https://www.ncbi.nlm.nih.gov/pubmed/22905434 
27. Phiri J, Ataguba JE. Inequalities in public health care delivery in Zambia. BioMed Central [Internet]. 2014; 1-9. Available from: https://doi.org/10.1186/1475-9276-13-24

28. BPJS Kesehatan. Daftar perusahaan asuransi swasta yang bekerja sama dengan BPJS Kesehatan melalui skema Coordination of Benefit (COB) [Internet]. 2016 [cited 2016 Oct 14]. Available from: http://bpjs-kesehatan.go.id/bpjs/index.php/post/read/2015/321/Daftar-51-
Perusahaan-Asuransi-Swasta-yang-Bekerjasama-dengan-BPJSKesehatan-melalui-Skema-Coordination-of-Benefit

29. BPJS Kesehatan. Peraturan badan penyelenggaran jaminan sosial kesehatan nomor 4 tahun 2016 tentang petunjuk teknis penyelenggaraan koordinasi manfaat dalam program jaminan kesehatan nasional. Jakarta: BPJS Kesehatan; 2016. 